\title{
The primary headaches: genetics, epigenetics and a behavioural genetic model
}

\author{
Pasquale Montagna
}

Received: 14 January 2008/ Accepted: 4 February 2008/Published online: 15 March 2008

(C) Springer-Verlag 2008

\begin{abstract}
The primary headaches, migraine with (MA) and without aura (MO) and cluster headache, all carry a substantial genetic liability. Familial hemiplegic migraine (FHM), an autosomal dominant mendelian disorder classified as a subtype of MA, is due to mutations in genes encoding neural channel subunits. MA/MO are considered multifactorial genetic disorders, and FHM has been proposed as a model for migraine aetiology. However, a review of the genetic studies suggests that the FHM genes are not involved in the typical migraines and that FHM should be considered as a syndromic migraine rather than a subtype of MA. Adopting the concept of syndromic migraine could be useful in understanding migraine pathogenesis. We hypothesise that epigenetic mechanisms play an important role in headache pathogenesis. A behavioural model is proposed, whereby the primary headaches are construed as behaviours, not symptoms, evolutionarily conserved for their adaptive value and engendered out of a genetic repertoire by a network of pattern generators present in the brain and signalling homeostatic imbalance. This behavioural model could be incorporated into migraine genetic research.
\end{abstract}

Keywords Migraine - Tension-type headache . Cluster headache $\cdot$ Genetics $\cdot$ Epigenetics

\section{Introduction}

The genetics of the primary headaches scored recent scientific successes due to the unravelling of the genetics of

\section{P. Montagna $(\varangle)$}

Department of Neurological Sciences,

University of Bologna Medical School,

Via Ugo Foscolo, 7, 40123 Bologna, Italy

e-mail: pmontagn@kaiser.alma.unibo.it
FHM. Deciphering of the patho-physiological mechanisms of these common diseases promises to bring the much needed knowledge for pharmacological treatments and therapeutic interventions. There are however also problems and controversies, some not solved by the genetic studies performed to date. The following is a brief subjective review of the available evidence, suggesting a role for epigenetic mechanisms and ending with the proposal of a behavioural model of the primary headaches possibly useful for the genetic studies.

Primary and secondary headaches: symptoms, syndromes or diseases? Idiopathic and syndromic migraines

Headaches/migraines are plagued by problems of definition: these terms describe symptoms (a feature which indicates a condition of disease, in particular one apparent to the patient, CED 2003), and at the same time, distinctive syndromes (a group of symptoms which consistently occur together) [1] or diseases (a disorder of structure or function in a human, animal, or plant, especially one that produces specific symptoms) [1] with recognisable diagnostic features, internationally defined [2]. The problems encountered with definitions become evident when dealing with primary or secondary headaches, and when considering idiopathic and syndromic migraines. Secondary headaches are those in which attacks occur due to a recognisable cause or disease, which itself represents the primary cause of the attacks. Syndromic migraines, contrasted with the idiopathic ones, are those in which attacks of migraine, clinically barely or not distinguishable from those occurring in the primary migraines, occur compounded with involvement of other systems. Syndromic migraines are 
often genetically determined. The concept of "syndromic," potentially useful in the exploration of headache pathogenesis, has been applied to conditions such as deafness, visual loss and epilepsy, but has no place in the HCS classification that classifies headache attacks and not diseases, albeit distinguishing between primary and secondary headaches. These considerations may apply to the genetics of the primary headaches, since by adopting the HCS (2004), we consider symptoms, not diseases (much as if, studying the genetics of diabetes mellitus, we adopted a classification of the hyperglycemias).

\section{Genetic epidemiology of the typical migraines}

The typical primary migraines (MO and MA) all have a substantial risk of familial recurrence. When estimating the population relative risk of migraine in specified groups of relatives (i.e. the ratio between the probability that a relative versus a random member of the population is affected), first-degree relatives of migraine without aura probands have 1.9 times the risk of MO and 1.4 times the risk of MA, whereas first-degree relatives of MA probands have nearly four times the risk of MA and no increased risk of MO [3]. Since a family aggregation is implied when the risk ratio exceeds one, this confirms the familial liability for the migraines, even though familiarity is not yet heredity. A further analysis showed however that spouses of MO probands have 1.4 times the risk of MO, and spouses of MA probands have no increased risk of MA [3], thus backing a hereditary liability for MO and especially MA. Twin studies concur with this increased familial liability. Concordance rates for migraine are consistently higher among monozygotic (MZ) than dizygotic (DZ) twins. In particular, heritability estimates were around 52\% in female twin pairs raised together or apart since infancy. In MZ Danish twin pairs, liability to $\mathrm{MO}$ resulted from additive genetic effects (61\%) and from individual-specific environmental effects (39\%), while in MA, correlation in liability was 0.68 in $\mathrm{MZ}$ and 0.22 in DZ, with heritability estimated at 0.65 . Therefore, twin studies reveal that approximately one-half of the variation in migraine is attributable to additive genes, while the remainder is caused by unshared rather than shared environmental factors between twins $[4,5]$. Several studies have analysed pedigrees with migraine, segregation analysis being performed to discover the genetic transmission pattern. Studies at first envisioned migraine as a simple mendelian disorder, inherited according to monogenic rules of transmission. Various modes of inheritance, autosomal dominant with female preponderance, possibly sex determined; autosomal recessive with $70 \%$ penetrance; polygenic; maternal and $\mathrm{X}$-linked transmissions have been proposed, or rejected
$[6,7]$. Finally, based on complex segregation analysis, a multifactorial inheritance was considered the most likely pattern even in high-risk families with MA [8]. A single gene was considered unlikely, but, notably, in some families, a mendelian or mitochondrial inheritance could not be excluded [3]. Currently, migraine is widely considered a complex disease with multifactorial inheritance. This type of inheritance applies to many complex/quantitative traits, i.e. traits that vary continuously in a phenotypic range, and in which variation is quantitative, not qualitative. Examples of quantitative traits are height, body weight, etc. Such traits are influenced by multiple genes (each a quantitative trait locus QTL), each having a small quantitative effect and interacting with the environment. However, there is still no unequivocal evidence that migraine as a quantitative trait varies continuously in the general population, and moreover, genetic variation underlying a continuous character distribution can result from segregation at a single locus too. Therefore, considering migraine as a quantitative trait may still be unwarranted.

The primary headaches also display considerable comorbidity, rarely incorporated into genetic studies. MA is comorbid with hypomania, depression and anxiety, and MO with phobia, panic and major depression. Other comorbidities are stroke, dyslipoproteinemias, essential tremor, paroxysmal dyskinesia and epilepsy. Merikangas et al. in a longitudinal genetic epidemiology study found that migraine was associated with mood disorders and drew attention to the fact that age at onset of anxiety disorders preceded, while onset of affective disorders followed that of migraine, findings consistent with a syndromic relationship between migraine and anxiety/depression [9].

These findings have been replicated, maternal depression being significantly associated with development of migraine in children [10]. Asthma, rhynitis and allergic bronchitis are also important comorbidities recurring in migraine families [11-13]. These comorbid clinical features should be properly incorporated in the genetic studies of the primary headaches.

\section{Mendelian migraines? The genetics of FHM and their putative relationship with the typical migraines MA/MO}

Migraines may be multifactorial, but mendelian migraines, i.e., migraines that conform to a mendelian type of genetic transmission, do exist. FHM is classified as a subtype of migraine with aura in the HCS (2004), and it conforms to an autosomal dominant pattern of hereditary transmission. Joutel et al. mapped FHM to chromosome 19, and in 1996 the first FHM gene, CACNL1A4, later termed CACNA1A, encoding the alpha1A subunit of the P/Q neural calcium 
channel, was discovered, accounting for both FHM 1 and episodic ataxia type 2 (EA2) phenotypes [14, 15]. Spinocerebellar atrophy type 6 (SCA6) was added to the FHM and EA2 phenotypes in 1997 [16]. Thus, FHM 1, EA2 and SCA6 are all allelic channelopathies, with missense mutations mostly accounting for FHM, mutations disrupting the reading frame for EA2 and polyglutamine expansions in the $\mathrm{COOH}$ gene terminal for SCA6. The phenotypic spectrum of the CACNA1A mutations was at first believed to consist either of pure FHM or of FHM associated with cerebellar atrophy. Why some mutations originate pure FHM while others elicit progressive or intermittent cerebellar features remains unclear [17]. Ictal coma after trivial trauma and essential tremor were associated clinical features in families harbouring particular CACNA1A mutations. The phenotypic spectrum of the CACNA1A mutations has further expanded to include ataxia induced by fever or high temperature [18], childhood epilepsy [19,20] and status epilepticus [21], paroxysmal paranoid psychosis with anxiety [22], benign paroxysmal torticollis of infancy, considered a migraine equivalent [23], and even myasthenic syndrome [24], since CACNA1A is also expressed on presynaptic neuromuscular junction terminals where it modulates transmitter release [25] even in the absence of any morphological changes in the junction or muscle weakness [26].

The paroxysmal clinical features of migraine, ataxia and epilepsy, together with the consideration that CACNA1A specifies for a calcium channel and that in the tottering and leaner mouse with epilepsy and ataxia, similar mutations are found in the mouse homologue of the calcium channel alpha1A subunit gene, led to the proposal that migraine be considered a calcium channelopathy [27]. The concept of migraine as a brain channelopathy fits well with the phenomenon of spreading depression [28], implicated in migraine attack pathophysiology. It is now accepted by the scientific community as an explicative model for migraine. However, the available genetic evidence is controversial or negative (see below).

FHM was soon proved to be genetically heterogeneous, some families linking to chromosome 1 [29,30], and a second gene, ATP1A2, encoding the alpha 2 subunit of the $\mathrm{Na} / \mathrm{K}$ ATPase, was discovered in Italian families and accounting for a phenotype of pure FHM (FHM 2) [31]. New mutations were found in FHM 2 pedigrees [32], and soon the phenotypic spectrum of FHM 2, initially thought to be confined to pure FHM, broadened to include such features as coma, triggered by minor head trauma and angiography [33], recurrent comas [34] and epilepsy, namely benign familial infantile febrile convulsions [35]. Finally, cerebellar ataxia associated with epilepsy and mental retardation was described in an Italian FHM 2 family [36,37], findings later confirmed by Spadaro et al. and Vanmolkot et al. in other families [38, 39]. Phenotypes of alternating hemiplegia of childhood [40-42] and basilar migraine [43] described with ATP1A2 mutations further enlarged the clinical spectrum of FHM 2. Variability within the same family is notable, with FHM, cerebellar ataxia, recurrent paroxysmal dystonia and mental retardation all recurring together [42].

Lastly, mutations in the neuronal voltage-gated sodium channel SCN1A were reported by Dichgans et al. [44] to account for a phenotype of pure FHM (FHM 3), and there are still FHM families without mutations in any of the previously described genes, implying further genetic heterogeneity. Sporadic patients with HM, more common in clinical practice, also present problems, since mutations in the known FHM genes are only rarely encountered in this population [45].

An important corollary of the genetic discoveries obtained in the FHM was the proposal to consider FHM as a model for the typical migraines MO and MA [27]. This spurred the search for the involvement of FHM genes in MO/MA. Up to now the effort has been largely unrewarding. This in our opinion is also due to the misclassification of FHM as a subtype of MA [2], whereas FHM represents a syndromic migraine (see below). Some evidence in favour of linkage of typical migraines to the FHM locus on chromosome 19 was initially offered by May et al. [46], Nyholt et al. [47] and Terwindt et al. [48]. However, early negative studies [49-51] were later substantiated by systematic screening investigations of the CACNA1A in families with MO and/or MA [52-55], and to date, mutations in CACNA1A have never been demonstrated in kindreds without hemiplegic migraine, with or without aura. The same negative considerations apply to ATP1A2. Earlier evidence in favour of a role of the Chrlq31 locus or ATP1A2 gene in the typical migraines [56, 57] was superseded by negative findings and absent ATP1A2 mutations in typical migraine only pedigrees, even those displaying an apparently autosomal dominant mode of inheritance [58-61]. The FHM 3 SCNIA gene was discovered too recently for any conclusive study. Von Brevern et al. [62] however failed to find any CACNA1A, ATPIA2 or SCN1A mutations in patients with migrainous vertigo. Thus, there is no current evidence that the genes causing FHM represent major susceptibility loci for the typical migraines.

Does such negative genetic evidence imply that FHM is not a useful model for migraine etiology? Several reviews of migraine pathogenesis apply the FHM model of neural channelopathy to the typical migraines. While such models are not justified genetically, it may be contended that FHM is nonetheless helpful in elucidating the pathophysiology of 
Table 1 A list of proposed (and provisional) syndromic migraines

\begin{tabular}{|c|c|c|}
\hline Syndromic migraines & Genes (chromosome) involved & Migrainous features (references) \\
\hline $\begin{array}{l}\text { MELAS (mitochondrial myopathy, encephalopathy, } \\
\text { lactic acidosis, and stroke-like episodes) }\end{array}$ & $\begin{array}{l}M T T L 1, M T T Q, M T T H, M T T K, M T T S 1, \\
\text { MTND1, MTND5, MTND6, and MTTS2 } \\
\text { (mtDNA) }\end{array}$ & $\begin{array}{l}\text { Most frequent symptom: episodic sudden } \\
\text { headache with vomiting and convulsions } \\
{[63,64]}\end{array}$ \\
\hline $\begin{array}{l}\text { CADASIL (cerebral arteriopathy, autosomal } \\
\text { dominant, with subcortical infarcts and } \\
\text { leukoencephalopathy) }\end{array}$ & NOTCH 3 (19p13.2-p13.1) & $\mathrm{MA}$ in $22 \%$ [65]; migraine in $38 \%$ [66] \\
\hline $\begin{array}{l}\text { HERNS (retinopathy, vascular, with cerebral and } \\
\text { renal involvement and Raynaud and migraine } \\
\text { phenomena) }\end{array}$ & TREX1 (3p21.3-p21.2) & Migraine in $70 \%$ [67] \\
\hline CCM (familial cerebral cavernous malformations) & KRYT $1(7 \mathrm{q} 11.2-\mathrm{q} 21)$ & Convulsions and migraine attacks $[68,69]$ \\
\hline
\end{tabular}

the migraine attacks. This consideration however is likely to apply to several clinical conditions all characterised by headache attacks of the migraine type. Migraine-like attacks indeed are found not only in the typical migraines, but also in other conditions, diseases or syndromes, in which they occur together with symptoms and signs of multisystem nervous or extra-nervous involvement. These "syndromic migraines" thus display bona fide migraine headache attacks at some times in their clinical course, and most of them have a genetic basis (Table 1). FHM is also characterised by multisystem neurologic involvement (migraine, hemiplegia, ictal recurrent comas, cerebellar atrophy, mental retardation, epilepsy, movement disorders, myasthenic syndrome, etc.), and therefore we make a plea for FHM to be considered more appropriately as a syndromic migraine and not a subtype of MA, as with the current HCS classification (2004).

\section{Linkage and association studies in the typical migraines}

Several studies on the genetics of the typical migraines MO and MA applied genetic association, linkage and genome wide scanning methods. Most of these studies resulted in findings that either lack verification or are controversial. For MA, a genome wide scan on 50 multigenerational families in Finland identified a susceptibility locus on chromosome $4 q 24$ [70]. Other loci for MA have been reported on chromosome 11q24 in Canadian families with an autosomal dominant transmission pattern [71], and on chromosome 15q11-q13 to a genomic region containing genes encoding for GABA-A receptors in ten Italian families again displaying an autosomal dominant transmission pattern [72].

For MO, or for pedigrees with MO mixed with MA, susceptibility loci have been reported on chromosome 6p12.2-p21.1 in Sweden [73], chromosome 5q21 [74], chromosome $14 \mathrm{q} 21.2-\mathrm{q} 22.3$ in an Italian family with MO [75], chromosome Xq24-28 in two large Australian pedigrees [76] and chromosome 19p13.3/2 to the insulin receptor gene INSR [77]. While many of such findings have still to be replicated, in some cases (the INSR gene) sequence studies have given negative results [78].

Other studies have examined candidate genes, implying that a pathogenetic (and a priori) hypothesis was formulated beforehand. This may be risky, considering that the pathogenesis of the migraine headaches is still imperfectly understood. Candidate genes explored were the mitochondrial DNA (mtDNA), or genes involved in prothrombotic or cardiovascular disease, or in the metabolism of biologic amines such as dopamine or serotonin, or in a variety of other metabolic systems. Several of the studies applied to mtDNA genes have yielded negative results, even though in some families migraine was reported to segregate with the Leber mtDNA 14484 mutation [79], and mtDNA mutations and haplotypes (haplotype $U$ ) have been associated with juvenile migraine stroke [80, 81] and with cyclic vomiting, considered a migraine equivalent in the pediatric population [82-84]. Contrasting results for genes involved in prothrombotic/cardiovascular risk, and for those involved in the metabolism of the biological amines serotonin and dopamine, or in several other metabolic pathways are summarised in Tables 2, 3, 4, and 5 .

Finally, a few studies have focused on the genetics of the chronic headaches, a major social problem, since these chronic headaches are often associated with drug abuse and afflict a remarkable percentage of the general population. Chronic tension-type headache displays a substantial familial recurrence, with lifetime relative risk estimated at 3.87 for parents and 3.53 for children of probands; the risk is greater for females (3.35) than for males (2.59) [85]. A genetic association study of chronic headache with drug abuse versus the dopamine metabolism genes by Cevoli et al. [86] found that allele 4 of the exon III VNTR polymorphism of the dopamine receptor 4 gene DRD 4 was associated with chronic daily headache, and allele 9 of the dopamine transporter gene SLC6A3 was more common in 
Table 2 Prothrombotic and cardiovascular risk genes and typical migraine genetics

\begin{tabular}{ll}
\hline $\begin{array}{l}\text { Prothrombotic/vascular risk genes } \\
\text { or mutations examined }\end{array}$ & Phenotypes \\
\hline $\begin{array}{l}\text { LDL receptor (19p13.2) } \\
\text { Factor V R/Q 506 (Leiden mutation) }\end{array}$ & $\begin{array}{l}\text { Associated with MO [87]; not associated [88] } \\
\text { Associated with MA [89] } \\
\text { Not associated with migraine stroke [90]; not } \\
\text { associated with MA/MO [91]; not associated with } \\
\text { juvenile MA [92] }\end{array}$ \\
$\begin{array}{l}\text { Not associated with MA/MO [91] } \\
\text { Factor II 20210 G/A }\end{array}$ & $\begin{array}{l}\text { Not associated with migraine stroke [93] } \\
\text { Not associated with migraine [94] }\end{array}$ \\
$\begin{array}{l}\text { Factor XIII Val 34 Leu } \\
\text { promoter }\end{array}$ & $\begin{array}{l}\text { Not associated with MA/MO [91] } \\
\text { Alloantigenic platelet systems HPA-1 and HPA-2 }\end{array}$ \\
$\begin{array}{l}\text { Deficit of protein S } \\
\text { Angiotensin converting enzyme (ACE) }\end{array}$ & $\begin{array}{l}\text { Associated with MA [89] } \\
\text { Allele D associated with MO and more frequent } \\
\text { migraine attacks [95] }\end{array}$ \\
$\begin{array}{l}\text { Endothelial NO synthase inducible (NOS3; iNOS) } \\
\text { Endothelin receptor A (ETA-231 A/G) }\end{array}$ & $\begin{array}{l}\text { Not associated with migraine [96, 97] } \\
\text { polymorphism }\end{array}$ \\
$\begin{array}{l}\text { MTHFR (methylene-tetra-hydrofolate reductase) } \\
\text { C677T/A1298C }\end{array}$ & $\begin{array}{l}\text { Homozygous mutation associated with MA [99], } \\
\text { associated with MA [100]; risk for MA, } \\
\text { modulated by thymidilate synthase gene [101] }\end{array}$ \\
&
\end{tabular}

Table 3 Serotonin metabolism genes and typical migraine genetics

\begin{tabular}{|c|c|}
\hline $\begin{array}{l}\text { Serotonin metabolism } \\
\text { genes examined }\end{array}$ & Phenotypes \\
\hline 5-HTSERT (17q11.2-12) & $\begin{array}{l}\text { Allelic association with MO (increase of allele STin2.12 + decrease of allele } \\
\text { STin2.10) and MA (same + increase of allele Stin2.9) [102]; 5HT-TLPR } \\
\text { with MA [103] } \\
\text { Allelic association with migraine (allele Stin2.10) [104]; borderline } \\
\text { association with migraine [105] } \\
\text { No association/linkage with migraine }[106,107]\end{array}$ \\
\hline $5-H T 2 A(13 \mathrm{q} 14-21)$ & $\begin{array}{l}\text { Allelic (allele C) association with migraine aura [108] } \\
\text { No association with migraine }[105,106,109,110]\end{array}$ \\
\hline $5-H T 1 B(6 \mathrm{q} 13)$ & No association with migraine $[106,110,111]$ \\
\hline 5-HT1D (1p36.3-34.3) & No association with migraine $[106,110,111]$ \\
\hline $5-H T 2 B(2 \mathrm{q} 36.3-\mathrm{q} 37.1)$ & No association with migraine $[106,110,111]$ \\
\hline $5-H T 2 C(\mathrm{Xq} 22-25)$ & No association with migraine $[106,110,111]$ \\
\hline $5-H T 1 B(6 \mathrm{q} 13)$ & No association with therapeutic response to triptans $[112,113]$ \\
\hline $5-H T 1 F(3 \mathrm{p} 12)$ & No association with therapeutic response to triptans $[112,113]$ \\
\hline
\end{tabular}

chronic daily headache associated with drug abuse than in episodic migraine.

\section{Genetics of tension-type headache}

Remarkably, apart from an epidemiological genetic study that demonstrated a familial aggregation for chronic tension-type headache [85], there are no other genetic studies of this common disorder.

\section{Genetics of cluster headache}

Cluster headache $(\mathrm{CH})$ has long been considered a sporadic disease. In recent decades, however, a familial recurrence has been appreciated, and the new HCS classification (2004) now states that $\mathrm{CH}$ may be transmitted as an autosomal dominant disease in about $5 \%$ of cases. Several $\mathrm{CH}$ cases have been reported among monozygotic twins and in family pedigrees [129-137], and family studies indicate that I-degree relatives of $\mathrm{CH}$ probands carry a 5- to 18-fold, and 
Table 4 Dopamine metabolism genes and typical migraine genetics

\begin{tabular}{|c|c|}
\hline Genes examined & Phenotypes \\
\hline Dopamine receptor $2(D R D 2)$ & $\begin{array}{l}\text { Allelic association (allele NcoI) with MA comorbid } \\
\text { with anxiety/depression [114] } \\
\text { Allelic association (allele 1) with yawning/nausea } \\
\text { during attack of MO [115] } \\
\text { No allelic association (allele NcoI) with MA [116] } \\
\text { No allelic association with MO/MA [107, 117, 118, } \\
\text { 119] }\end{array}$ \\
\hline $\begin{array}{l}\text { Dopamine receptors } 1,3,4,5 \text { (DRD1, DRD3, } \\
\text { DRD4, DRD5) }\end{array}$ & No allelic association with migraine $[115,117,120]$ \\
\hline Dopamine transporter $(D A T)$ & $\begin{array}{l}\text { Association with chronic daily headache with drug } \\
\text { abuse [86] }\end{array}$ \\
\hline COMT; $M A O-A$ & No association with migraine $[117,121]$ \\
\hline Dopamine-betahydroxylase $(D B H)$ & $\begin{array}{l}\text { Association with migraine [107], especially males with } \\
\text { MA [122] } \\
\text { No association [123] }\end{array}$ \\
\hline
\end{tabular}

\begin{tabular}{ll}
\hline Genes examined & Phenotypes \\
\hline Androgen/progesterone receptors & $\begin{array}{c}\text { Androgen receptor not associated; progesterone receptor } \\
\text { associated with migraine [124] }\end{array}$ \\
K channel $K C N N 3$ & Allelic association (CAG repeats) with MO/MA [125] \\
& Not associated (CAG repeats) [126] \\
Cytotoxic T lymphocyte antigen 4 & Not associated with migraine [127] \\
$(C T L A-4)$ & Allelic association with MA [128] \\
HLA-DRB1 &
\end{tabular}

Table 5 Other genes implicated in typical migraine genetics

\section{Genetics and epigenetics}

II-degree relatives a 1- to 3 -fold increased relative risk of the disease [138-141]. CH has been considered a probable autosomal dominant disease with a penetrance of $0.3-0.34$ in males and 0.17-0.21 in females [142]. The exact transmission pattern is however still debated [143, 144], and an autosomal recessive pattern has been advocated in certain families [137]. Several candidate genes have been analysed, in particular mtDNA mutations [145-148], HLA antigens [149-151] and CACNA1A polymorphisms [152, 153], usually with negative or controversial results. Other genes, such as the NO synthases NOS1, NOS2A and NOS3 [154], the elusive amine gene cluster [155], the CLOCK gene involved in the regulation of circadian rhythms $[156,157]$ and the hemochromatosis gene [158], have been found not associated with $\mathrm{CH}$. Recently, an association between $\mathrm{CH}$ and a polymorphism in the hypocretin receptor 2 gene HCRTR2 was reported by Rainero et al. [159], possibly accounting for the circadian recurrence of the $\mathrm{CH}$ attacks. Such an association, while confirmed by Schürks et al. [160], was rejected in a European multicentric study [161]. Recently, reports of $\mathrm{CH}$ associated with hemiparesis during the attacks suggested a relationship with FHM and ionic channelopathies [162]. Preliminary genic expression studies instead documented the activation of proinflammatory genes during the $\mathrm{CH}$ attack [163].
Epigenetics is the study of the changes in DNA and DNAbinding proteins that, albeit altering the structure of chromatin, do not modify the nucleotide sequence of DNA. The remarkable feature here is that some of these modifications may be associated with heritable changes in gene function.

Commonly held concepts of heredity indeed pit environmental influences (nurture) against genetic background (nature) as totally separate causative factors. Genetic advances themselves have however demonstrated that the hereditary transmission of biological changes not encoded in the DNA sequence and dictated by environmental influences is possible. This part of genetics, called epigenetics, has received little or no attention in the genetic studies of the primary headaches. It is the contention of the author however that future epigenetic studies will account for several hereditary features of the primary headaches, in particular their comorbidities.

All those (meiotic and mitotic) modifications in gene expression that are heritable but not encoded in the DNA sequence are defined as epigenetic. Molecular mechanisms implicated include (1) methylation of cytosine residues at C5 in dinucleotide $\mathrm{CpG}$ sites (localised especially in promoters of well over $40 \%$ of the genes and that, when 
methylated, cause silencing of the gene); (2) mechanisms of RNA interference, whereby microRNAs silence gene expression; (3) histone (DNA associated proteins) changes: activation or inactivation of genomic regions according to the "histone code". All of these mechanisms result in the expression or silencing of genes, and underlie such phenomena as inactivation of the $\mathrm{X}$ chromosome and genomic imprinting. Several epigenetic diseases are already known that may be inherited through the somatic and the germinal line: fragile $\mathrm{X}$ syndrome, in which ATRX gene mutations modify the methylation pattern of ribosomial RNA and, by methylation of CGG expansions in the FMRI gene, silence the gene; the Angelman and Prader-Willi, and Rett syndromes; also, many colonic cancers and leukemias. Important epigenetic differences that increase with age are found even between monochorial twins [164]. Notably, epigenetic modifications may increase with age and may also be prevented through interventions directed at DNA or histone methylation (with azanucleotides, antisense oligonucleotides, histone deacetylase). Even more remarkably, there is some evidence that lifestyles and even diet may play a role [165].

\section{Epigenetic models for the primary headaches?}

There is consistent evidence that behavioural differences typical of specific inbred animal strains are the consequence of environmental influences acting especially during development rather than DNA changes. Mice strains with decreased environmental exploration behaviour (B6 strain) develop enhanced exploratory behaviour if nurtured in their first 3 months of life by BALB dams, a strain displaying intense exploratory behaviour; changes in behaviour appear to be linked to the type of maternal care, particularly licking of the pup by the mother, a behaviour demonstrated to affect the status of the endocrine stress system in mice [166]. Weaver et al. [167] showed how maternal care in the rat (licking and grooming the pup) modifies the methylation pattern of the promoter of the glucocorticoid receptor gene in the hippocampus; such epigenetic changes, evident from the first week of life, persist throughout the animal's life but are reversible upon treatment with histone deacetylase inhibitors or upon intracerebral administration of methionine (an intervention that modifies the methylation pattern) [168].

Stress plays a remarkable role in the development of the nervous system: removal of rat pups from the mother causes reduced neurogenesis in the adult hippocampus through steroid-dependent mechanisms [169], and alters serotonergic transporter densities and serotonergic $1 \mathrm{~A}$ receptors in the rat brain [170]. Administration of steroids to the mother before delivery causes changes in behavioural patterns in juvenile rats [171], and maternal deprivation in the immediate post-natal period modifies locomotor and steroid release patterns in the adult rat [172]. Epigenetic mechanisms also seem relevant for the formation of memory traces [173] and more generally for cognitive development [174]. Epigenetic mechanisms have been hypothesised for psychiatric disorders $[175,176]$ and many complex and multifactorial diseases affecting the brain or the inflammatory and immune systems [177-179].

There are still no studies of epigenetic mechanisms in the primary headaches. When considering, however, the important maternal influence in migraine genetics; the consistent and inherited co-morbidities especially for psychiatric and inflammatory-immune disorders; twin studies documenting that only about half of the variability is due to "genetic" factors; it is possible to envision that epigenetic mechanisms, especially those acting during nervous system development in early infancy and childhood, play a role in the heritability and pathophysiology of the primary headaches. Preliminary studies have already analysed attachment styles in adult migraineurs [180, 181], and a prospective investigation demonstrated correlations between events suffered during pregnancy and early life, and quality of adult life 31-33 years later [182]. It is reasonable to suggest that early life factors and attachment styles between mother and child represent determinants of epigenetic changes relevant in migraine pathogenesis. Such early pre- and post-natal environmental behavioural factors could be usefully analysed to define endophenotypes of adaptive behaviour useful in the genetic studies of the primary headaches.

\section{Final comments: a behavioural model of the primary headaches as fight-or-flight response and sickness behaviour to be incorporated into genetic research}

Consideration of epigenetic mechanisms may help in analysing behaviours during the headache attacks. Any genetic studies are ultimately dependent upon the definition of the phenomenon taken into consideration, and on how it is conceptualised. Therefore, studies have to rely upon conventional diagnostic criteria, in turn based on a priori interpretations. Most genetic studies have been performed within the frame of migraine interpreted simply as a "pain" trait with multifactorial inheritance. In a "harlequin" model, several genetic factors, each one having a small specific weight, interact with environmental factors to determine the migraine attack. Such a model should however be better tailored to suit phenomena such as the migraine attack and the migraine diseases that are really behavioural "processes" with an intrinsic logic of their own [183], one that is consistent within attacks, within 
patients and within populations. There is a need to conceive of the primary headaches along more useful scientific lines. Consistently lacking in the genetic studies is for instance any consideration of migraine as a behavioural response to environmental and/or endogenous triggers, a view that has scientific support [184] and that we recently revised to accomodate a Darwinian perspective [185]. According to our view, migraine and other primary headaches such as $\mathrm{CH}$ are behaviours, not symptoms, evolutionarily conserved for their adaptive value and engendered out of a genetic repertoire by networks of pattern generators present in the brain. These neural networks serve the homeostasis of the brain, with migraine pain considered a kind of visceral pain signalling homeostatic imbalance. The behavioural repertoire enacted during the migraine attack, complete with its full panoply of pain, cognitive, autonomic, motor, etc., symptoms and signs, is comparable to that defined as sickness behaviour and already known to develop in all mammals and other animals following challenge with infective and other pathogenic agents [186]. In contrast, behaviour during the $\mathrm{CH}$ attacks [187] resembles the fight-or-flight response of hypothalamic animals. These behaviours during the headache attacks really represent "healing" processes, and migraine may even be evolutionarily advantageous [188]. Thus, what is relevant in this new behavioural model is not the manifestations of the attack, but the factors triggering it, that, migraine being of the brain, must relate to still unknown disturbances of brain homeostasis [185]. Accordingly, it is these triggering factors rather than the manifestations during the attacks that may represent the features most relevant for a true dissection of the genetics of the primary headaches.

Acknowledgments I wish to thank Ms. A. Laffi for help with the manuscript, and A. Collins for revising the English text. Supported by MIUR grants. This review results from the lesson of the Author at the Master in Headache Medicine, Sapienza University of Rome, during the Academic Year 2007-2008.

\section{References}

1. The Compact English Dictionary, IInd edn. Oxford University Press, Oxford, pp 1-1378

2. Headache Classification Subcommittee of the International Headache Society (2004) The international classification of headache disorders. Cephalalgia 24:1-160

3. Russell MB, Iselius L, Olesen J (1996) Migraine without aura and migraine with aura are inherited disorders. Cephalalgia 16:305-309

4. Ulrich V, Gervil M, Kyvik KO, Olesen J, Russell MB (1999) The inheritance of migraine with aura estimated by means of structural equation modelling. J Med Genet 36:225-227

5. Russell MB, Ulrich V, Gervil M, Olesen J (2002) Migraine without aura and migraine with aura are distinct disorders. A population-based twin survey. Headache 42:332-336
6. Devoto M, Lozito A, Staffa G, D'Alessandro R, Sacquegna T, Romeo G (1986) Segregation analysis of migraine in 128 families. Cephalalgia 6:101-105

7. Mochi M, Sangiorgi S, Cortelli P, Carelli V, Scapoli C, Crisci M, Monari L, Pierangeli G, Montagna P (1993) Testing models for genetic determination in migraine. Cephalalgia 13:389-394

8. Ulrich V, Russell MB, Ostergaard S, Olesen J (1997) Analysis of 31 families with an apparently autosomal-dominant transmission of migraine with aura in the nuclear family. Am J Med Genet 74:395-397

9. Merikangas KR, Merikangas JR, Angst J (1993) Headache syndromes and psychiatric disorders: association and familial transmission. J Psychiatr Res 27:197-210

10. Mortimer MJ, Kay J, Jaron A, Good PA (1992) Does a history of maternal migraine or depression predispose children to headache and stomach-ache? Headache 32:353-355

11. Chen TC, Leviton A (1990) Asthma and eczema in children born to women with migraine. Arch Neurol 47:1227-1230

12. Mortimer MJ, Kay J, Gawkrodger DJ, Jaron A, Barker DC (1993) The prevalence of headache and migraine in atopic children: an epidemiological study in general practice. Headache 33:427-431

13. Gurkan F, Ece A, Haspolat K, Dikici B (2000) Parental history of migraine and bronchial asthma in children. Allergol Immunopathol (Madr) 28:15-17

14. Joutel A, Bousser MG, Biousse V, Labauge P, Chabriat H, Nibbio A, Maciazek J, Meyer B, Bach MA, Weissenbach J et al (1993) A gene for familial hemiplegic migraine maps to chromosome 19. Nat Genet 5:40-45

15. Ophoff RA, Terwindt GM, Vergouwe MN, van Eijk R, Oefner PJ, Hoffman SM, Lamerdin JE, Mohrenweiser HW, Bulman DE, Ferrari M, Haan J, Lindhout D, van Ommen GJ, Hofker MH, Ferrari MD, Frants RR (1996) Familial hemiplegic migraine and episodic ataxia type- 2 are caused by mutations in the Ca2+ channel gene CACNL1A4. Cell 87:543-552

16. Zhuchenko O, Bailey J, Bonnen P, Ashizawa T, Stockton DW, Amos C, Dobyns WB, Subramony SH, Zoghbi HY, Lee CC (1997) Autosomal dominant cerebellar ataxia (SCA6) associated with small polyglutamine expansions in the alpha 1A-voltagedependent calcium channel. Nat Genet 15:62-69

17. Alonso I, Barros J, Tuna A, Seixas A, Coutinho P, Sequeiros J, Silveira I (2004) A novel R1347Q mutation in the predicted voltage sensor segment of the P/Q-type calcium-channel alphasubunit in a family with progressive cerebellar ataxia and hemiplegic migraine. Clin Genet 65:70-72

18. Subramony SH, Schott K, Raike RS, Callahan J, Langford LR, Christova PS, Anderson JH, Gomez CM (2003) Novel CACNA1A mutation causes febrile episodic ataxia with interictal cerebellar deficits. Ann Neurol 54:725-731

19. Jouvenceau A, Eunson LH, Spauschus A, Ramesh V, Zuberi SM, Kullmann DM, Hanna MG (2001) Human epilepsy associated with dysfunction of the brain P/Q-type calcium channel. Lancet 358:801-807

20. Kors EE, Melberg A, Vanmolkot KR, Kumlien E, Haan J, Raininko R, Flink R, Ginjaar HB, Frants RR, Ferrari MD, van den Maagdenberg AM (2004) Childhood epilepsy, familial hemiplegic migraine, cerebellar ataxia, and a new CACNA1A mutation. Neurology 63:1136-1137

21. Beauvais K, Cave-Riant F, De Barace C, Tardieu M, TournierLasserve E, Furby A (2004) New CACNA1A gene mutation in a case of familial hemiplegic migraine with status epilepticus. Eur Neurol 52:58-61

22. Spranger M, Spranger S, Schwab S, Benninger C, Dichgans M (1999) Familial hemiplegic migraine with cerebellar ataxia and paroxysmal psychosis. Eur Neurol 41:150-152 
23. Giffin NJ, Benton S, Goadsby PJ (2002) Benign paroxysmal torticollis of infancy: four new cases and linkage to CACNA1A mutation. Dev Med Child Neurol 44:490-493

24. Maselli RA, Kong DZ, Bowe CM, McDonald CM, Ellis WG, Agius MA, Gomez CM, Richman DP, Wollmann RL (2000) Presynaptic congenital myasthenic syndrome due to quantal release deficiency. Neurology 57:279-289

25. Plomp JJ, Vergouwe MN, van den Maagdenberg AM, Ferrari MD, Frants RR, Molenaar PC (2000) Abnormal transmitter release at neuromuscular junctions of mice carrying the tottering alpha(1A) $\mathrm{Ca}(2+)$ channel mutation. Brain 123(Pt 3):463-471

26. Kaja S, van de Ven RC, Broos LA, Veldman H, van Dijk JG, Verschuuren JJ, Frants RR, Ferrari MD, van den Maagdenberg AM, Plomp JJ (2005) Gene dosage-dependent transmitter release changes at neuromuscular synapses of CACNA1A R192Q knockin mice are non-progressive and do not lead to morphological changes or muscle weakness. Neuroscience 135:81-95

27. Terwindt GM, Ophoff RA, Haan J, Sandkuijl LA, Frants RR, Ferrari MD (1998) Migraine, ataxia and epilepsy: a challenging spectrum of genetically determined calcium channelopathies. Dutch Migraine Genetics Research Group. Eur J Hum Genet 6:297-307

28. van den Maagdenberg AM, Pietrobon D, Pizzorusso T, Kaja S, Broos LAM, Cesetti T, van de Ven RCG, Tottene A, van der Kaa J, Plomp JJ, Frants RR, Ferrari MD (2004) A Cacna1A knockin migraine mouse model with increased susceptibility to cortical spreading depression. Neuron 41:701-710

29. Gardner K, Barmada MM, Ptacek LJ, Hoffman EP (1997) A new locus for hemiplegic migraine maps to chromosome 1q31. Neurology 49:1231-1238

30. Ducros A, Joutel A, Vahedi K, Cecillon M, Ferreira A, Bernard E, Verier A, Echenne B, Lopez de Munain A, Bousser MG, Tournier-Lasserve E (1997) Mapping of a second locus for familial hemiplegic migraine to $1 \mathrm{q} 21-\mathrm{q} 23$ and evidence of further heterogeneity. Ann Neurol 42:885-890

31. De Fusco M, Marconi R, Silvestri L, Atorino L, Rampoldi L, Morgante L, Ballabio A, Aridon P, Casari G (2003) Haploinsufficiency of ATP1A2 encoding the $\mathrm{Na}+\mathrm{K}+$ pump alpha 2 subunit associated with familial hemiplegic migraine type 2 . Nat Genet 33:192-196

32. Riant F, De Fusco M, Aridon P, Ducros A, Ploton C, Marchelli F, Maciazek J, Bousser MG, Casari G, Tournier-Lasserve E (2005) ATP1A2 mutations in 11 families with familial hemiplegic migraine. Hum Mutat 26:281

33. Pierelli $F$ et al (2006) A novel ATP1A2 mutation in a family with FHM type II. Cephalalgia 26:324-328

34. Echenne B, Ducros A, Rivier F, Joutel A, Humbertclaude V, Roubertie A, Azais M, Bousser MG, Tournier-Lasserve E (1999) Recurrent episodes of coma: an unusual phenotype of familial hemiplegic migraine with linkage to chromosome 1. Neuropediatrics 30:214-217

35. Vanmolkot KR, Kors EE, Hottenga JJ, Terwindt GM, Haan J, Hoefnagels WA, Black DF, Sandkuijl LA, Frants RR, Ferrari MD, van den Maagdenberg AM (2003) Novel mutations in the $\mathrm{Na}+, \mathrm{K}+$-ATPase pump gene ATP1A2 associated with familial hemiplegic migraine and benign familial infantile convulsions. Ann Neurol 54:360-366

36. Cevoli S, Pierangeli G, Monari L, Valentino ML, Bernardoni P, Mochi M, Cortelli P, Montagna P (2002) Familial hemiplegic migraine: clinical features and probable linkage to chromosome 1 in an Italian family. Neurol Sci 23:7-10

37. Jurkat-Rott K, Freilinger T, Dreier JP, Herzog J, Gobel H, Petzold GC, Montagna P, Gasser T, Lehmann-Horn F, Dichgans M (2004) Variability of familial hemiplegic migraine with novel A1A2 Na+/K+-ATPase variants. Neurology 62:1857-1861
38. Spadaro M, Ursu S, Lehmann-Horn F, Liana V, Antonini G, Giunti P, Frontali M, Jurkat-Rott K (2004) A G301R Na+/K+ ATPase mutation causes familial hemiplegic migraine type 2 with cerebellar signs. Neurogenetics 5:177-185

39. Vanmolkot KR, Stroink H, Koenderink JB, Kors EE, van den Heuvel JJ, van den Boogerd EH, Stam AH, Haan J, De Vries BB, Terwindt GM, Frants RR, Ferrari MD, van den Maagdenberg AM (2006) Severe episodic neurological deficits and permanent mental retardation in a child with a novel FHM2 ATP1A2 mutation. Ann Neurol 59:310-314

40. Bassi MT, Bresolin N, Tonelli A, Nazos K, Crippa F, Baschirotto C, Zucca C, Bersano A, Dolcetta D, Boneschi FM, Barone V, Casari G (2004) A novel mutation in the ATP1A2 gene causes alternating hemiplegia of childhood. J Med Genet 41:621-628

41. Auvin S, Joriot-Chekaf S, Cuvellier JC, Vallee L (2004) Familial alternating hemiplegia of childhood or channelopathy? A report with valuable pathophysiological implications. Dev Med Child Neurol 46:500

42. Swoboda KJ, Kanavakis E, Xaidara A, Johnson JE, Leppert MF, Schlesinger-Massart MB, Ptacek LJ, Silver K, Youroukos S (2004) Alternating hemiplegia of childhood or familial hemiplegic migraine? A novel ATP1A2 mutation. Ann Neurol 55:884-887

43. Ambrosini A, D’Onofrio M, Grieco GS, Di Mambro A, Montagna G, Fortini D, Nicoletti F, Nappi G, Sances G, Schoenen J, Buzzi MG, Santorelli FM, Pierelli F (2005) Familial basilar migraine associated with a new mutation in the ATP1A2 gene. Neurology 65:1826-1828

44. Dichgans M, Freilinger T, Eckstein G, Babini E, Lorenz B, Biskup S, Ferrari MD, Herzog J, van den Maagdenberg AM, Pusch M, Strom TM (2005) Mutation in the neuronal voltagegated sodium channel SCN1A in familial hemiplegic migraine. Lancet 366:371-377

45. Terwindt $\mathrm{G}$ et al (2002) Mutation analysis of the CACNA1A calcium channel subunit gene in 27 patients with sporadic hemiplegic migraine. Arch Neurol 59:1016-1018

46. May A, et al (1995) Familial hemiplegic migraine locus on 19 p13 is involved in the common forms of migraine with and without aura. Hum Genet 96:604-608

47. Nyholt DR et al (1998) Familial typical migraine: linkage to chromosome 19p13 and evidence for genetic heterogeneity. Neurology 50:1428-1432

48. Terwindt GM et al (2001) Involvement of the CACNA1A gene containing region on 19p13 in migraine with and without aura. Neurology 56:1028-1032

49. Hovatta I et al (1994) Familial migraine: exclusion of the susceptibility gene from the reported locus of familial hemiplegic migraine on 19p. Genomics 23:707-709

50. Monari L et al (1997) Searching for migraine genes: exclusion of $290 \mathrm{cM}$ out of the whole human genome. Ital J Neurol Sci $18: 277-282$

51. Kim JS et al (1998) Familial migraine with vertigo: no mutations found in CACNA1A. Am J Med Genet 79:148-151

52. Brugnoni $\mathrm{R}$ et al (2002) Is the CACNA1A gene involved in familial migraine with aura? Neurol Sci 23:1-5

53. Noble-Topham S et al (2001) Migraine with aura is not linked to the FHM gene CACNA1A or the chromosomal region, $19 \mathrm{p} 13$. Genomics 78:150-154

54. Jones KW et al (2002) Migraine with aura susceptibility locus on chromosome $19 \mathrm{p} 13$ is distinct from the familial hemiplegic migraine locus. Neurology 59:1099-1101

55. Wieser $\mathrm{T}$ et al (2003) Absence of known familial hemiplegic migraine (FHM) mutations in the CACNA1A gene in patients with common migraine: implications for genetic testing. Clin Chem Lab Med 41:272-275 
56. Todt $\mathrm{U}$ et al (2005) Rare missense variants in ATP1A2 in families with clustering of common forms of migraine. Hum Mutat 26:315-321

57. Lea RA et al (2002) A typical migraine susceptibility region localizes to chromosome 1q31. Neurogenetics 4:17-22

58. Curtain RP et al (2005) Analysis of chromosome 1 microsatellite markers and the FHM2-ATP1A2 gene mutations in migraine pedigrees. Neurol Res 27:647-652

59. Jen JC, Kim GW, Dudding KA, Baloh RW (2004) No mutations in CACNA1A and ATP1A2 in probands with common types of migraine. Arch Neurol 61:926-928

60. Kirchmann M et al (2006) The CACNA1A and ATP1A2 genes are not involved in dominantly inherited migraine with aura. Am J Med Genet B Neuropsychiatr Gen 141:250-256

61. Netzer C et al (2006) Haplotype-based systematic association studies of ATP1A2 in migraine with aura. Am J Med Genet 141:257-260

62. von Brevern $M$ et al (2006) Migrainous vertigo: mutation analysis of the candidate genes CACNA1A, ATP1A2, SCN1A, and CACNB4. Headache 46:1136-1141

63. Goto Y, Horai S, Matsuoka T, Koga Y, Nihei K, Kobayashi M, Nonaka I (1992) Mitochondrial myopathy, encephalopathy, lactic acidosis, and stroke-like episodes (MELAS): a correlative study of the clinical features and mitochondrial DNA mutation. Neurology 42:545-550

64. Montagna P, Gallassi R, Medori R, Govoni E, Zeviani M, Di Mauro S, Lugaresi E, Andermann F (1988) MELAS syndrome: characteristic migrainous and epileptic features and maternal transmission. Neurology 38:751-754

65. Chabriat H, Vahedi K, Iba-Zizen MT, Joutel A, Nibbio A, Nagy TG, Krebs MO, Julien J, Dubois B, Ducrocq X, Levasseur M, Homeyer P, Mas JL, Lyon-Caen O, Tournier Lasserve E, Bousser MG (1995) Clinical spectrum of CADASIL: a study of 7 families. Lancet 346:934-939

66. Dichgans M, Mayer M, Uttner I, Bruning R, Muller-Hocker J, Rungger G, Ebke M, Klockgether T, Gasser T (1998) The phenotypic spectrum of CADASIL: clinical findings in 102 cases. Ann Neurol 44:731-739

67. Ophoff RA, DeYoung J, Service SK, Joosse M, Caffo NA, Sandkuijl LA, Terwindt GM, Haan J, van den Maagdenberg AMJM, Jen J, Baloh RW, Barilla-LaBarca M-L, Saccone NL, Atkinson JP, Ferrari MD, Freimer NB, Frants RR (2001) Hereditary vascular retinopathy, cerebroretinal vasculopathy, and hereditary endotheliopathy with retinopathy, nephropathy, and stroke map to a single locus on chromosome 3p21.1-p21.3. Am J Hum Genet 69:447-453

68. Michael JC, Levin PM (1936) Multiple telangiectases of brain: a discussion of hereditary factors in their development. Arch Neurol Psychiatry 36:514-536

69. Marini V, Ferrera L, Dorcaratto A, Viale G, Origone P, Mareni C, Garrè C (2003) Identification of a novel KRIT1 mutation in an Italian family with cerebral cavernous malformation by the protein truncation test. J Neurol Sci 212:75-78

70. Wessman M, Kallela M, Kaunisto MA, Marttila P, Sobel E, Hartiala J, Oswell G, Leal SM, Papp JC, Hämäläinen E, Broas P, Joslyn G, Hovatta I, Hiekkalinna T, Kaprio J, Ott J, Cantor RM, Zwart JA, Ilmavirta M, Havanka H, Färkkilä M, Peltonen L, Palotie A (2002) A susceptibility locus for migraine with aura on chromosome 4q24. Am J Hum Genet 70:652-62

71. Cader ZM, Noble-Topham S, Dyment DA, Cherny SS, Brown JD, Rice GP, Ebers GC (2003) Significant linkage to migraine with aura on chromosome 11q24. Hum Mol Genet 12:25112517

72. Russo L, Mariotti P, Sangiorgi E, Giordano T, Ricci I, Lupi F, Chiera R, Guzzetta F, Neri G, Gurrieri F (2005) A new susceptibility locus for migraine with aura in the 15q11-q13 genomic region containing three GABA-A receptor genes. Am J Hum Genet 76:327-333

73. Carlsson A, Forsgren L, Nylander PO, Hellman U, ForsmanSemb K, Holmgren G, Holmberg D, Holmberg M (2002) Identification of a susceptibility locus for migraine with and without aura on 6p12.2-p21.1. Neurology 59:1804-1807

74. Nyholt DR, Morley KI, Ferreira MA, Medland SE, Boomsma DI, Heath AC, Merikangas KR, Montgomery GW, Martin NG (2005) Genomewide significant linkage to migrainous headache on chromosome 5q21. Am J Hum Genet 77:500-512

75. Soragna D, Vettori A, Carraro G, Marchioni E, Vazza G, Bellini S, Tupler R, Savoldi F, Mostacciuolo ML (2003) A locus for migraine without aura maps on chromosome 14q21.2-q22.3. Am J Hum Genet 72:161-167

76. Nyholt DR, Curtain RP, Griffiths LR (2000) Familial typical migraine: significant linkage and localization of a gene to Xq2428. Hum Genet 107:18-23

77. McCarthy LC, Hosford DA, Riley JH, Bird MI, White NJ, Hewett DR, Peroutka SJ, Griffiths LR, Boyd PR, Lea RA, Bhatti SM, Hosking LK, Hood CM, Jones KW, Handley AR, Rallan R, Lewis KF, Yeo AJ, Williams PM, Priest RC, Khan P, Donnelly C, Lumsden SM, O'Sullivan J, See CG, Smart DH, ShawHawkins S, Patel J, Langrish TC, Feniuk W, Knowles RG, Thomas M, Libri V, Montgomery DS, Manasco PK, Xu CF, Dykes C, Humphrey PP, Roses AD, Purvis IJ (2001) Singlenucleotide polymorphism alleles in the insulin receptor gene are associated with typical migraine. Genomics 78:135-149

78. Curtain R, Tajouri L, Lea R, MacMillan J, Griffiths L (2006) No mutations detected in the INSR gene in a chromosome 19p13 linked migraine pedigree. Eur J Med Genet 49:57-62

79. Cupini LM, Massa R, Floris R, Manenti G, Martini B, Tessa A, Nappi G, Bernardi G, Santorelli FM (2003) Migraine-like disorder segregating with mtDNA 14484 Leber hereditary optic neuropathy mutation. Neurology 60:717-719

80. Ojaimi J, Katsabanis S, Bower S, Quigley A, Byrne E (1998) Mitochondrial DNA in stroke and migraine with aura. Cerebrovasc Dis 8:102-106

81. Majamaa K, Finnilä S, Turkka J, Hassinen IE (1998) Mitochondrial DNA haplogroup U as a risk factor for occipital stroke in migraine. Lancet 352:455-456

82. Boles RG, Williams JC (1999) Mitochondrial disease and cyclic vomiting syndrome. Dig Dis Sci 44:103S-107S

83. Boles RG, Adams K, Ito M, Li BU (2003) Maternal inheritance in cyclic vomiting syndrome with neuromuscular disease. Am J Med Genet A 120:474-482

84. Salpietro CD, Briuglia S, Merlino MV, Di Bella C, Rigoli L (2003) A mitochondrial DNA mutation (A3243G mtDNA) in a family with cyclic vomiting. Eur J Pediatr 162:727-728

85. Russell MB, Ostergaard S, Bendtsen L, Olesen J (1999) Familial occurrence of chronic tension-type headache. Cephalalgia 19:207-210

86. Cevoli S, Mochi M, Scapoli C, Marzocchi N, Pierangeli G, Pini LA, Cortelli P, Montagna P (2006) A genetic association study of dopamine metabolism-related genes and chronic headache with drug abuse. Eur J Neurol 13:1009-1013

87. Mochi M, Cevoli S, Cortelli P, Pierangeli G, Scapoli C, Soriani S, Montagna P (2003) Investigation of an LDLR gene polymorphism (19p13.2) in susceptibility to migraine without aura. J Neurol Sci 213:7-10

88. Curtain R, Lea RA, Quinlan S, Bellis C, Tajouri L, Hughes R, Macmillan J, Griffiths LR (2004) Investigation of the lowdensity lipoprotein receptor gene and cholesterol as a risk factor for migraine. J Neurol Sci 227:95-100

89. D'Amico D, Moschiano F, Leone M, Ariano C, Ciusani E, Erba N, Grazzi L, Ferraris A, Schieroni F, Bussone G (1998) Genetic abnormalities of the protein $\mathrm{C}$ system: shared risk factors in 
young adults with migraine with aura and with ischemic stroke? Cephalalgia 18:618-621

90. Haan J, Kappelle LJ, de Ronde H, Ferrari MD, Bertina RM (1997) The factor V Leiden mutation (R506Q) is not a major risk factor for migrainous cerebral infarction. Cephalalgia 17:605-607

91. Corral J, Iniesta JA, González-Conejero R, Lozano ML, Rivera J, Vicente V (1998) Migraine and prothrombotic genetic risk factors. Cephalalgia 18:257-260

92. Soriani S, Borgna-Pignatti C, Trabetti E, Casartelli A, Montagna P, Pignatti PF (1998) Frequency of factor V Leiden in juvenile migraine with aura. Headache 38:779-781

93. Haan J, Kappelle LJ, Ferrari MD, Bertina RM (1998) The transition $\mathrm{G}$ to $\mathrm{A}$ at position 20210 in the 3'-untranslated region of the prothrombin gene is not associated with migrainous infarction. Cephalalgia 18:229-230

94. Iniesta JA, Corral J, González-Conejero R, Díaz Ortuño A, Martínez Navarro ML, Vicente V (2001) Role of factor XIII Val 34 Leu polymorphism in patients with migraine. Cephalalgia 21:837-841

95. Paterna S, Di Pasquale P, D'Angelo A, Seidita G, Tuttolomondo A, Cardinale A, Maniscalchi T, Follone G, Giubilato A, Tarantello M, Licata G (2000) Angiotensin-converting enzyme gene deletion polymorphism determines an increase in frequency of migraine attacks in patients suffering from migraine without aura. Eur Neurol 43:133-136

96. Griffiths LR, Nyholt DR, Curtain RP, Goadsby PJ, Brimage PJ (1997) Migraine association and linkage studies of an endothelial nitric oxide synthase (NOS3) gene polymorphism. Neurology 49:614-617

97. Lea RA, Curtain RP, Shepherd AG, Brimage PJ, Griffiths LR (2001) No evidence for involvement of the human inducible nitric oxide synthase (iNOS) gene in susceptibility to typical migraine. Am J Med Genet 105:110-113

98. Tzourio C, El Amrani M, Poirier O, Nicaud V, Bousser MG, Alpérovitch A (2001) Association between migraine and endothelin type A receptor (ETA-231 A/G) gene polymorphism. Neurology 56:1273-1277

99. Kowa H, Yasui K, Takeshima T, Urakami K, Sakai F, Nakashima K (2000) The homozygous C677T mutation in the methylenetetrahydrofolate reductase gene is a genetic risk factor for migraine. Am J Med Genet 96:762-764

100. Kara I, Sazci A, Ergul E, Kaya G, Kilic G (2003) Association of the C677T and A1298C polymorphisms in the 5,10 methylenetetrahydrofolate reductase gene in patients with migraine risk. Brain Res Mol Brain Res 111:84-90

101. Oterino A, Valle N, Pascual J, Bravo Y, Muñoz P, Castillo J, Ruiz-Alegría C, Sánchez- Velasco P, Leyva-Cobián F, Cid C (2005) Thymidylate synthase promoter tandem repeat and MTHFD1 R653Q polymorphisms modulate the risk for migraine conferred by the MTHFR T677 allele. Brain Res Mol Brain Res 139:163-168

102. Ogilvie AD, Russell MB, Dhall P, Battersby S, Ulrich V, Smith CA, Goodwin GM, Harmar AJ, Olesen J (1998) Altered allelic distributions of the serotonin transporter gene in migraine without aura and migraine with aura. Cephalalgia 18:23-26

103. Borroni B, Brambilla C, Liberini P, Rao R, Archetti S, Gipponi S, Volta GD, Padovani A (2005) Functional serotonin 5-HTTLPR polymorphism is a risk factor for migraine with aura. J Headache Pain 6:182-184

104. Yilmaz M, Erdal ME, Herken H, Cataloluk O, Barlas O, Bayazit YA (2001) Significance of serotonin transporter gene polymorphism in migraine. J Neurol Sci 186:27-30

105. Juhasz G, Zsombok T, Laszik A, Gonda X, Sotonyi P, Faludi G, Bagdy G (2003) Association analysis of 5-HTTLPR variants,
5-HT2a receptor gene 102T/C polymorphism and migraine. J Neurogenet 17:231-240

106. Monari L, Mochi M, Valentino ML, Arnaldi C, Cortelli P, De Monte A, Pierangeli G, Prologo G, Scapoli C, Soriani S, Montagna P (1997) Searching for migraine genes: exclusion of $290 \mathrm{cM}$ out of the whole human genome. Ital J Neurol Sci 18:277-282

107. Lea RA, Dohy A, Jordan K, Quinlan S, Brimage PJ, Griffiths LR (2000) Evidence for allelic association of the dopamine betahydroxylase gene (DBH) with susceptibility to typical migraine. Neurogenet 3:35-40

108. Erdal ME, Herken H, Yilmaz M, Bayazit YA (2001) Association of the T102C polymorphism of 5-HT2A receptor gene with aura in migraine. J Neurol Sci 188:99-101

109. Nyholt DR, Curtain RP, Gaffney PT, Brimage P, Goadsby PJ, Griffiths LR (1996) Migraine association and linkage analyses of the human 5-hydroxytryptamine (5HT2A) receptor gene. Cephalalgia 16:463-467

110. Buchwalder A, Welch SK, Peroutka SJ (1996) Exclusion of 5-HT2A and 5-HT2C receptor genes as candidate genes for migraine. Headache 36:254-258

111. Johnson MP, Lea RA, Curtain RP, MacMillan JC, Griffiths LR (2003) An investigation of the 5-HT2C receptor gene as a migraine candidate gene. Am J Med Genet B Neuropsychiatr Genet 117:86-89

112. MaassenVanDenBrink A, Reekers M, Bax WA, Ferrari MD, Saxena PR (1998) Coronary side-effect potential of current and prospective antimigraine drugs. Cirgulation 98:25-30

113. MaassenVanDenBrink A, Vergouve MN, Ophoff RA, Saxena PR, Ferrari MD, Frants RR (1998) 5-HT1B receptor polymorphism and clinical response to sumatriptan. Headache 38:288291

114. Peroutka SJ, Price SC, Wilhoit TL, Jones KW (1998) Comorbid migraine with aura, anxiety, and depression is associated with dopamine D2 receptor (DRD2) NcoI alleles. Mol Med 4:14-21

115. Del Zompo M, Cherchi A, Palmas MA, Ponti M, Bocchetta A, Gessa GL, Piccardi MP (1998) Association between dopamine receptor genes and migraine without aura in a Sardinian sample. Neurology 51:781-786

116. Dichgans M, Förderreuther S, Deiterich M, Pfaffenrath V, Gasser T (1998) The D2 receptor NcoI allele: absence of allelic association with migraine with aura. Neurology 51(3):928

117. Montagna P, Cevoli S, Marzocchi N, Pierangeli G, Pini LA, Cortelli P, Mochi M (2003) The genetics of chronic headaches. Neurol Sci 24:S51-S56

118. Maude S, Curtin J, Breen G, Collier D, Russell G, Shaw D, Clair DS (2001) The -141C Ins/Del polymorphism of the dopamine D2 receptor gene is not associated with either migraine or Parkinson's disease. Psychiatr Genet 11:49-52

119. Rebaudengo N, Rainero I, Parziale A, Rosina F, Pavanelli E, Rubino E, Mazza C, Ostacoli L, Furlan PM (2004) Lack of interaction between a polymorphism in the dopamine D2 receptor gene and the clinical features of migraine. Cephalalgia 24:503-507

120. Shepherd AG, Lea RA, Hutchins C, Jordan KL, Brimage PJ, Griffiths LR (2002) Dopamine receptor genes and migraine with and without aura: an association study. Headache 42:346-351

121. Marziniak M, Mössner R, Benninghoff J, Syagailo YV, Lesch KP, Sommer C (2004) Association analysis of the functional monoamine oxidase A gene promotor polymorphism in migraine. J Neural Transm 111:603-609

122. Fernandez F, Lea RA, Colson NJ, Bellis C, Quinlan S, Griffiths LR (2006) Association between a 19 bp deletion polymorphism at the dopamine beta-hydroxylase (DBH) locus and migraine with aura. J Neurol Sci 251:118-123 
123. Mochi M, Cevoli S, Cortelli P, Pierangeli G, Soriani S, Scapoli C, Montagna P (2003) A genetic association study of migraine with dopamine receptor 4, dopamine transporter and dopaminebeta-hydroxylase genes. Neurol Sci 23:301-305

124. Colson NJ, Lea RA, Quinlan S, MacMillan J, Griffiths LR (2005) Investigation of hormone receptor genes in migraine. Neurogenetics 6:17-23

125. Mössner R, Weichselbaum A, Marziniak M, Freitag CM, Lesch KP, Sommer C, Meyer J (2005) A highly polymorphic polyglutamine stretch in the potassium channel $\mathrm{KCNN} 3$ in migraine. Headache 45:132-136

126. Curtain R, Sundholm J, Lea R, Ovcaric M, MacMillan J, Griffiths L (2005) Association analysis of a highly polymorphic CAG Repeat in the human potassium channel gene KCNN3 and migraine susceptibility. BMC Med Genet 14:32-39

127. Lulli P, Trabace S, Morellini M, Cicciarelli G, Coloprisco G, Piane M, de Filippis S, Santi PG, Avramakou O, Ferlicca E, Martelletti $\mathrm{P}$ (2005) Cytotoxic T lymphocyte antigen 4 polymorphism $49(\mathrm{~A}>\mathrm{G})$ and migraine. J Headache Pain 6:188190

128. Rainero I, Fasano E, Rubino E, Rivoiro C, Valfrè W, Gallone S, Savi L, Gentile S, Lo Giudice R, De Martino P, Dall'Omo AM, Pinessi L (2005) Association between migraine and HLA-DRB1 gene polymorphisms. J Headache Pain 6:185-187

129. Couturier EG, Hering R, Steiner TJ (1991) The first report of cluster headache in identical twins. Neurology 41:761

130. Roberge C, Bouchard JP, Simard D, Gagné R (1992) Cluster headache in twins. Neurology 42:1255-1256

131. Schuh-Hofer S, Meisel A, Reuter U, Arnold G (2003) Monozygotic twin sisters suffering from cluster headache and migraine without aura. Neurology 60:1864-1865

132. Sjaastad O, Shen JM, Stovner LJ, Elsås T (1993) Cluster headache in identical twins. Headache 33:214-217

133. Spierings EL, Vincent AJ (1992) Familial cluster headache: occurrence in three generations. Neurology 42:1399-1400

134. Alberca R, Aguilera JM, Casado JL, López JM, Arenas C, Moreno A, Serrano V (1994) Cluster headache with a familial presentation. Neurologia 9:22-24

135. Bordini CA, Arruda MA, Ciciarelli M, Daripa M, Martins Coelho J, Speciali JG (1997) Cluster headache: report of seven cases in three families. Funct Neurol 12:277-282

136. D’Amico D, Leone M, Moschiano F, Bussone G (1996) Familial cluster headache: report of three families. Headache 36:41-43

137. De Simone R, Fiorillo C, Bonuso S, Castaldo G (2003) A cluster headache family with possible autosomal recessive inheritance. Neurology 61:578-579

138. Russell MB, Andersson PG, Thomsen LL (1995) Familial occurrence of cluster headache. J Neurol Neurosurg Psychiatry 58:341-343

139. Russell MB, Andersson PG, Thomsen LL, Iselius L (1995) Cluster headache is an autosomal dominantly inherited disorder in some families: a complex segregation analysis. J Med Genet 32:954-956

140. Russell MB, Andersson PG, Iselius L (1996) Cluster headache is an inherited disorder in some families. Headache 36:608-612

141. Montagna P, Mochi M, Prologo G, Sangiorgi S, Pierangeli G, Cavoli S, Cortelli P (1998) Heritability of cluster headache. Eur J Neurol 5:343-345

142. Russell MB (2004) Epidemiology and genetics of cluster headache. Lancet Neurol 3:279-283

143. El Amrani M, Ducros A, Boulan P, Aidi S, Crassard I, Visy JM, Tournier-Lasserve E, Bousser MG (2002) Familial cluster headache: a series of 186 index patients. Headache 42:974-977

144. Svensson D, Ekbom K, Pedersen NL, Träff H, Waldenlind E (2003) A note on cluster headache in a population-based twin register. Cephalalgia 23:376-380
145. Shimomura T, Kitano A, Marukawa H, Mishima K, Isoe K, Adachi Y, Takahashi K (1994) Point mutation in platelet mitochondrial tRNA (Leu(UUR)) in patient with cluster headache. Lancet 344:625

146. Cortelli P, Zacchini A, Barboni P, Malpassi P, Carelli V, Montagna P (1995) Lack of association between mitochondrial tRNA(Leu(UUR)) point mutation and cluster headache. Lancet 345:1120-1121

147. Seibel P, Grünewald T, Gundolla A, Diener HC, Reichmann H (1996) Investigation on the mitochondrial transfer RNA(Leu)(UUR) in blood cells from patients with cluster headache. J Neurol 243:305-307

148. Odawara M, Tamaoka A, Mizusawa H, Yamashita K (1997) A case of cluster headache associated with mitochondrial DNA deletions. Muscle Nerve 20:394-395

149. Cuypers J, Altenkirch H (1979) HLA antigens in cluster headache. Headache 19:228-229

150. Martelletti P, Romiti A, Gallo MF, Giacovazzo M, Adorno D, Valeri M, Piazza A, Monaco PI, Casciani CU (1984) HLA-B14 antigen in cluster headache. Headache 24:152-154

151. Giacovazzo M, Martelletti P, Romiti A, Gallo MF, Iuvara E, Valeri M, Piazza A, Adorno D, Monaco PI, Casciani CU (1986) Genetic markers of cluster headache and the links with the lithium salts therapy. Int J Clin Pharmacol Res 6:19-22

152. Sjöstrand C, Giedratis V, Ekbom K, Waldenlind E, Hillert J (2001) CACNA1A gene polymorphisms in cluster headache. Cephalalgia 21:953-958

153. Haan J, van Vliet JA, Kors EE, Terwindt GM, Vermeulen FL, van den Maagdenberg AM, Frants RR, Ferrari MD (2001) No involvement of the calcium channel gene (CACNA1A) in a family with cluster headache. Cephalalgia 21:959-962

154. Sjöstrand C, Modin H, Masterman T, Ekbom K, Waldenlind E, Hillert J (2002) Analysis of nitric oxide synthase genes in cluster headache. Cephalalgia 22:758-764

155. Aridon P, D'Andrea G, Rigamonti A, Leone M, Casari G, Bussone G (2004) Elusive amines and cluster headache: mutational analysis of trace amine receptor cluster on chromosome 6q23. Neurol Sci 25(Suppl 3):S279-S280

156. Cevoli S, Mochi M, Pierangeli G, Zanigni S, Grimaldi D, Bonavina G, Torelli P, Manzoni GC, Cortelli P, Montagna P (2008) Investigation of the T3111C CLOCK gene polymorphism in cluster headache. J Neurol Feb 20 [Epub ahead of print]

157. Rainero I, Rivoiro C, Gallone $S$, Valfrè W, Ferrero M, Angilella G, Rubino E, De Martino P, Savi L, Lo Giudice R, Pinessi L (2005) Lack of association between the $3092 \mathrm{~T} \rightarrow \mathrm{C}$ Clock gene polymorphism and cluster headache. Cephalalagia 25:10781081

158. Rainero I, Rivoiro C, Rubino E, Milli V, Valfrè W, De Martino P, Lo Giudice R, Angilella G, Savi L, Gallone S, Pinessi L (2005) Prevalence of HFE (hemochromatosis) gene mutations in patients with cluster headache. Headache 45:1219-1223

159. Rainero I, Gallone S, Valfrè W, Ferrero M, Angilella G, Rivoiro C, Rubino E, De Martino P, Savi L, Ferrone M, Pinessi L (2004) A polymorphism of the hypocretin receptor 2 gene is associated with cluster headache. Neurology 63:1286-1288

160. Schürks M, Kurth T, Geissler I, Tessmann G, Diener HC, Rosskopf D (2006) Cluster headache is associated with the G1246A polymorphism in the hypocretin receptor 2 gene. Neurology 66:1917-1919

161. Baumber L, Sjöstrand C, Leone M, Harty H, Bussone G, Hillert J, Trembath RC, Russell MB (2006) A genome-wide scan and HCRTR2 candidate gene analysis in a European cluster headache cohort. Neurology 66:1888-1893

162. Siow HC, Young WB, Peres MF, Rozen TD, Silberstein SD (2002) Hemiplegic cluster. Headache 42:136-139 
163. Sjöstrand C, Duvefelt K, Steinberg A, Remahl IN, Waldenlind E, Hillert J (2006) Gene expression profiling in cluster headache: a pilot microarray study. Headache 46:1518-1534

164. Fraga MF, Ballestar E, Paz MF, Ropero S, Setien F, Ballestar ML, Heine-Suñer D, Cigudosa JC, Urioste M, Benitez J, BoixChornet M, Sanchez-Aguilera A, Ling C, Carlsson E, Poulsen P, Vaag A, Stephan Z, Spector TD, Wu YZ, Plass C, Esteller M (2005) Epigenetic differences arise during the lifetime of monozygotic twins. Proc Natl Acad Sci USA 102:10604-10609

165. Oommen AM, Griffin JB, Sarath G, Zempleni J (2005) Roles for nutrients in epigenetic events. J Nutr Biochem 16:74-77

166. Champagne FA, Francis DD, Mar A, Meaney MJ (2003) Variations in maternal care in the rat as a mediating influence for the effects of environment on development. Physiol Behav 79:359371

167. Weaver IC, Cervoni N, Champagne FA, D'Alessio AC, Sharma S, Seckl JR, Dymov S, Szyf M, Meaney MJ (2004) Epigenetic programming by maternal behavior. Nat Neurosci 7:847-854

168. Weaver IC, Champagne FA, Brown SE, Dymov S, Sharma S, Meaney MJ, Szyf M (2005) Reversal of maternal programming of stress responses in adult offspring through methyl supplementation: altering epigenetic marking later in life. J Neurosci 25:11045-11054

169. Karten YJ, Olariu A, Cameron HA (2005) Stress in early life inhibits neurogenesis in adulthood. Trends Neurosci 28:171-172

170. Vicentic A, Francis D, Moffett M, Lakatos A, Rogge G, Hubert GW, Harley J, Kuhar MJ (2006) Maternal separation alters serotonergic transporter densities and serotonergic 1A receptors in rat brain. Neuroscience 140:355-365

171. Burlet G, Fernette B, Blanchard S, Angel E, Tankosic P, Maccari S, Burlet A (2005) Antenatal glucocorticoids blunt the functioning of the hypothalamic-pituitary-adrenal axis of neonates and disturb some behaviors in juveniles. Neuroscience 133:221-230

172. Yoshihara T, Otsuki Y, Yamazaki A, Honma S, Yamasaki Y, Honma K (2005) Maternal deprivation in neonatal rats alters the expression of circadian system under light-dark cycles and restricted daily feeding in adulthood. Physiol Behav 85:646-654

173. Levenson JM, Sweatt JD (2005) Epigenetic mechanisms in memory formation. Nat Rev Neurosci 6:108-118

174. Hong EJ, West AE, Greenberg ME (2005) Transcriptional control of cognitive development. Curr Opin Neurobiol 15:2128
175. Petronis A (2004) The origin of schizophrenia: genetic thesis, epigenetic antithesis, and resolving synthesis. Biol Psychiatry 55:965-970

176. Gottesman II, Hanson DR (2005) Human development: biological and genetic processes. Annu Rev Psychol 56:263-286

177. Bjornsson HT, Fallin MD, Feinberg AP (2004) An integrated epigenetic and genetic approach to common human disease. Trends Genet 20:350-358

178. Jirtle RL, Skinner MK (2007) Environmental epigenomics and disease susceptibility. Nat Rev Genet 8:253-262

179. Vercelli D (2004) Genetics, epigenetics, and the environment: switching, buffering, releasing. J Allergy Clin Immunol 113:381-386

180. Savi L, Buccheri R, Tambornini A, De Martino P, Albasi C, Pinessi L (2005) Attachment styles and headache. J Headache Pain 6:254-257

181. Rossi P, Di Lorenzo G, Malpezzi MG, Di Lorenzo C, Cesarino F, Faroni J, Siracusano A, Troisi A (2005) Depressive symptoms and insecure attachment as predictors of disability in a clinical population of patients with episodic and chronic migraine. Headache 45:561-570

182. Ventegodt S, Flensborg-Madsen T, Andersen NJ, Merrick J (2005) Events in pregnancy, delivery, and infancy and long-term effects on global quality of life: results from the Copenhagen Perinatal Birth Cohort 1959-61. Med Sci Monit 11:CR357CR365

183. Blau JN (1992) Migraine: theories of pathogenesis. Lancet 339:1202-1209

184. Welch KM (1986) Migraine: a biobehavioural disorder. Cephalalgia 6:103-110

185. Montagna P, Cortelli P (2008) Migraine and the autonomic nervous system. In: Low PA (ed) Clinical autonomic disorders: evaluation and management. Lippincott, Williams and Wilkins, Philadelphia (in press)

186. Hart BL (1988) Biological basis of the behavior of sick animals. Neurosci Biobehav Rev 12:123-137

187. Blau JN (1993) Behaviour during a cluster headache. Lancet 342:723-725

188. Loder E (2002) What is the evolutionary advantage of migraine? Cephalalgia 22:624-32 